\title{
Legal Examination of the Constitutional Court Number 28/PUU-XI/2013 Concerning the Case of Judicial Review of Law Number 17 of 2012 Concerning Cooperatives
}

\author{
Lauddin Marsuni $^{1}$, Salle Salle ${ }^{1}$, Syarifuddin Syarifuddin ${ }^{1} \&$ La Ode Husen ${ }^{1}$ \\ ${ }^{1}$ Faculty of Law, Universitas Muslim Indonesia, Indonesia \\ Correspondence: La Ode Husen, Professor of the Faculty of Law, Universitas Muslim Indonesia, Indonesia. Tel: \\ 62-81-721-1784. E-mail: laode.husen@umi.ac.id
}

Received: March 6, 2020

doi:10.5539/ass.v16n5p42
Accepted: April 21, $2020 \quad$ Online Published: April 30, 2020

URL: https://doi.org/10.5539/ass.v16n5p42

\begin{abstract}
This study aims to understand the legal review on Decision of the Constitutional Court No. 28/PUU-XI/2013 on the review of Law No. 17 of 2012 on Cooperatives against The 1945 Constitution. The benefits of this research are socialization and provide legal awareness about cooperatives activities in Indonesia. This research uses a normative approach that focuses on studying the legal and regulatory norms associated with the object of the problem. The technical analysis used in this study is the Hermeneutic and Interpretation analysis methods. The results of the study indicate that Phrase "natural person" in the cooperatives sense was based on Article 1 point 1 of Law No. 17 of 2012 is against Article 33 section (1) of The 1945 Constitution because that definition leads to individualism. Furthermore, although the Petitioner's petition is only regarding certain articles it contains substantial norm content, it will cause other articles in Law No. 17 of 2012 has no binding legal force. Therefore the Petitioner's petition must be declared in accordance with the law for all contents of Law No. 17 of 2012. As for the sake of legal certainty, Law No. 25 of 1992 valid for a while awaiting the establishment of a new Law.
\end{abstract}

Keywords: Cooperatives, Decision, Review of Law, The Constitutional Court

\section{Introduction}

Cooperatives are a means of gathering together with the principle of joint efforts to create welfare conditions for citizens so that with these conditions, social justice for all Indonesian citizens as the ideals of the nation can be realized. The important role of cooperatives is the basis for economic growth in Indonesia. Based on Article 33 section (1) of The 1945 Constitution of the Republic of Indonesia (The 1945 Constitution) regulating that "The economy is to be structured as a common endeavor based on familial principles". Furthermore, based on the consideration of letter a of Law of the Republic of Indonesia Number 17 of 2012 on Cooperatives (Law No. 17 of 2012) states that:

"National economic development aims to realize Indonesia's political and economic sovereignty through the management of economic resources in the climate of development and empowerment of cooperatives that have a strategic role in national economic governance based on the familial principles and economic democracy in order to create a progressive, just and prosperous society based on Pancasila and The 1945 Constitution of the Republic of Indonesia"

The cooperatives, according to Mohammad Hatta (2002, p. 215), as the founding fathers of the nation, states that:

“... Familial principles are cooperatives. The Familial principles is a term in education that shows the relationship between teachers and students who live as one family. This is the pattern of Indonesian cooperatives, where the relationship between cooperatives members must reflect a sense of brotherhood, like family. A sense of solidarity is nurtured and strengthened. Members are educated to be people who have individuality who are aware of their self-esteem. If he realizes his pride as a member of cooperatives, he will have a great enthusiasm to fight for the interests of the cooperatives... Individuality is different from individualism. Individualism is a selfish attitude at the expense of the interests of others, while Individuality makes cooperatives members as defenders and fighters of cooperatives ..." 
From the above explanation, it is very clear that cooperatives are a means of gathering together which cannot be established and managed by individuals, even the existence of cooperatives as a defensive reflex against economic domination and exploitation by global capitalism against small groups in Indonesia (Hendrojogi, 2007, p. 6). But at present, several cooperatives are established and managed by individuals, for example, Oasis Cooperatives in Kutai Kartanegara Regency, which collects 700 truck drivers where the driver is charged Rp. 25,000 for once transporting of coal. Oasis Cooperatives activities are to advocate for truck drivers with the company if one day the driver suffers a work accident in the mining area. However, Oasis Cooperatives does not provide guarantees if the company does not provide compensation for medical expenses for cooperatives members due to work accidents in the mining area (Yuwana, Nugroho, \& Abdullah, 2012, p. 15).

The above conditions indicate the existence of cooperatives based on Article 1 point 1 of Law No. 17 of 2012 states that:

"Cooperatives are a legal entity established by a natural person or a cooperatives legal entity, with the separation of wealth from each of its members as capital to managed a business, which meets the aspirations and shared needs in the economic, social and cultural fields based on cooperatives values and principles."

The above provisions regulate cooperatives established and managed by individuals or legal entities in which the two phrases focus on capital or not based on solidarity and familial, which allows cooperatives owners to ignore familial principles. Therefore, Law No. 17 of 2012 submitted to the Constitutional Court as based on Article 24C section (1) of The 1945 Constitution regulating that "The Constitutional Court shall have the authority to make final decisions in cases of first and last instance handling the review of laws against the Constitution .." jo. Article 10 section (1) letter a of Law of the Republic of Indonesia Number 4 of 2014 on the enactment of Government Regulation in Lieu of Law Number 1 of 2013 on the Second Amendment to Law Number of Tahun 2003 on the Constitutional Court as a Law (Law No. 4 of 2014) regulating that "The Constitutional Court shall have the authority to make final decisions in cases of first and last instance handling the review of laws against The 1945 Constitution of the Republic of Indonesia".

Based on the description above, the purpose of this study is to understand the legal review on Decision of the Constitutional Court of the Republic of Indonesia Number 28/PUU-XI/2013 on the review of Law of the Republic of Indonesia Number 17 of 2012 on Cooperatives against The 1945 Constitution of the Republic of Indonesia (Decision of the Constitutional Court No. 28/PUU-XI/2013). The benefits of this research are socialization and provide legal awareness about cooperatives activities in Indonesia.

\section{Method}

This research uses a normative approach that focuses on studying the principles of legislation associated with the object of the problem (Begem, Qamar, \& Baharuddin, 2019, p. 3). The object of this research of Decision of the Constitutional Court No. 28/PUU-XI/2013 No. 28/PUU-XI/2013 which is the primary legal material. Secondary data is the minutes of case No. 28/PUU-XI/2013. The technical analysis used in this research is the Hermeneutic and Interpretation analysis method. The hermeneutic analysis is used to understand the text as a series of signs arranged in a particular way by the author to convey certain meanings (Gracia, 1990, p. 496), in this case Decision of the Constitutional Court No. 28/PUU-XI/2013 No. 28/PUU-XI/2013 and the minutes of case No. 28/PUU-XI/2013. Interpretation analysis is used to interpret and reveal the ontological, epistemological, and axiological essence (Hastangka, Armawi, \& Kaelan, 2018, p. 232) of each posita and petition in Decision of the Constitutional Court No. 28/PUU-XI/2013.

\section{Results and Discussion}

\subsection{Formal Requirements for Submitting a Petition}

Academically known 3 (three) forms of legal products, namely (i) Legislation (regeling); (ii) determination (beschikking) and (iii) Judgment (judgment, or Vonnis) (Asshiddiqie, 2006, p. 1). Law No. 17 of 2012 is one form of law in the form of legislation (regeling). Based on Article 7 section (1) of Law of the Republic of Indonesia Number 12 of 2011 on Legislation Making (Law No. 12 of 2011) regulating that types and hierarchy of Legislation are as follows (Marsuni, 2017, pp. 9 - 11):

a. The 1945 Constitution of the Republic of Indonesia;

b. The People's Consultative Assembly Decision;

c. Law/Government Regulation in Lieu of Law;

d. Government Regulation;

e. Presidential Regulation; 
f. Provincial Regulation; and

g. Regency/Municipal Regulation.

\subsubsection{Authority of the Constitutional Court}

Amendments to the 1945 Constitution where new institutions have been formed based on Article 7B, Article 24 section (1) and section (2), and Article 24C of The 1945 Constitution and further regulated on Law No. 24 of 2003 as amended by the Law No. 4 of 2014. One of the authorities of the Constitutional Court is handling the review of laws against The 1945 Constitution as based on Article 24C section (1) of The 1945 Constitution regulating that "The Constitutional Court shall have the authority to make final decisions in cases of first and last instance handling the review of laws against the Constitution ...". Furthermore based on Article 10 section (1) letter a of Law No. 4 of 2014 jo. Article 29 section (1) letter a of Law of the Republic of Indonesia Number 48 of 2009 on The Judicial Powers (Law No. 48 of 2009) regulating that "The Constitutional Court shall have the authority to make final decisions in cases of first and last instance handling the review of laws against The 1945 Constitution of the Republic of Indonesia".

The above provisions state that anyone and or any institution can submit a petition for the review of laws against The 1945 Constitution, must go to the Constitutional Court.

\subsubsection{Principal Case}

On February 13, 2013, the Petitioner consisted of:

a. Cooperatives Association Employee of the Republic of Indonesia (GKPRI) as Petitioner 1;

b. Village Unit Cooperatives Center (PUSKUD) as Petitioner 2;

c. Women's Cooperatives Center of East Java (Puskowanjati) as Petitioner 3;

d. An-Nisa' Cooperatives Center of East Java as Petitioner 4;

e. BUEKA Assakinah Cooperatives Center of East Java as Petitioner 5;

f. Cooperatives Association of Indonesian Milk as Petitioner 6;

g. Agung Haryono, Member of the Employee Cooperatives of the Republic of Indonesia (KPRI) State University of Malang as Petitioner 7; dan

h. Mulyono, Retired Telkom Employees as Petitioner 8.

Submit a petition for the review of Law No. 17 of 2012 [Article 1 point 1, Article 50 section (1), Article 55 section (1), Article 56 section (1) Article 66, Article 67, Article 68, Article 69, Article 70, Article 71, Article 72, Article 73, Article 74, Article 75, Article 76, Article 77, Article 80, Article 82, and Article 83] against The 1945 Constitution of the Republic of Indonesia to the Constitutional Court and accepted by the Registrar of the Constitutional Court based on the Deed of Acceptance of a petition file No. 89/PAN.MK/2013 and has been recorded in the Constitutional Case Registration Book on March 1, 2013, with No. 28/PUU-XI/2013. On April 3, 2013 , the petition file petitioner submitted again after repairs and received it on the same date. Whereas the trial portion of the case ruling consisted of nine Constitutional Court judges, including Hamdan Zoelva as chairman and concurrently a member, Arief Hidayat, Ahmad Fadlil Sumadi, Maria Farida Indrati, Patrialis Akbar, Muhammad Alim, Anwar Usman, Aswanto, and Wahiduddin Adams, each as a member.

\subsubsection{Legal Standing of the Petitioners}

Legal standing is a requirement that must be fulfilled by every petitioner to submit a petition for the review of laws against the 1945 Constitution to the Constitutional Court based on Article 51 section (1) of Law No. 17 of 2012 regulating that Petitioners are parties who consider their constitutional rights and/or authorities impaired by the coming into effect of the law, namely:

a. individual Indonesian citizens;

b. customary law community units as long as they are still alive and in accordance with community development and the principles of The Unitary State of the Republic of Indonesia as stipulated in the law;

c. public or private legal entity; or

d. state institutions.

The above provisions set two conditions that must be fulfilled to test whether the Petitioner has legal standing in the case of a review of the law, namely fulfilling the requirements to act as a petitioner, and there are constitutional rights and/or authorities of the Petitioner who have been impaired by the coming into of the law. 
That also becomes the core of the question at the first trial in the case No. 28/PUU-XI/2013, where M. Akil Mochtar as chairman and concurrently a member asked the following questions:

"Fine, please provide an explanation, while we have read this petition ... what's the point ... main points from the arguments of your petitions, so that we can understand briefly what exactly the Petitioner's wishes on this Cooperatives Law. Maybe starting from what point... if the point of the authority of the Constitutional Court is certain because this is a review of laws against The 1945 Constitution. Legal standing, maybe you need to explain ..."

Based on the description above, a trial can be conducted if the petitioner ensures the complete legal standing of the petition for the review of laws against the 1945 Constitution.

\subsection{Constitutional Impairment of the Petitioner}

Whereas Petitioner 1 - Petitioner 6 as private legal entities and Petitioner 7 and Petitioner 8 as individual Indonesian citizens constitutionally, it has been impaired in fulfilling its Constitutional Rights to uphold and comply with the rules contained in the Law a quo, because:

3.2.1 Article 1 point 1 of Law No. 17 of 2012

Based on Article 1 point 1 of Law No. 17 of 2012 states that:

"Cooperatives are a legal entity established by a natural person or a cooperatives legal entity, with the separation of wealth from each of its members as capital to managed a business, which meets the aspirations and shared needs in the economic, social and cultural fields based on cooperatives values and principles."

The above provisions explain that cooperatives are established by a natural person to produce priority individual welfare, not the welfare of members. Also, the definition of related cooperatives is set by individuals, so that the principles of togetherness and familial will not be realized. The article is against Article 33 section (1) of The 1945 Constitution regulating that "The economy is to be structured as a common endeavor based on familial principles". Further explanation of Article 33 of the 1945 Constitution as the historical foundation of cooperatives states that there is a basis for economic democracy, production is carried out by all, for all under the leadership or supervision of members of the community. The welfare of community members comes first, not individual welfare. Therefore cooperatives are established together based on familial principles.

Explanation of Article 33 can be understood that the meaning of cooperatives based on the 1945 Constitution must contain elements:

- The basis of economic development is economic democracy;

- $\quad$ The spirit of joint effort (collectivism);

- $\quad$ Oriented towards shared prosperity, not individuals.

3.2.2 Article 37 section (1) letter f; and Article 57 section (2) of Law No. 17 of 2012

Based on Article 37 section (1) letter f of Law No. 17 of 2012 regulating that "In a Member Meeting ..., The Organizer must submit an annual accountability report containing compensation for the Trustee as well as salary and other allowances for the Organizer".

Based on Article 57 section (2) of Law No. 17 of 2012 regulating that "Salaries and allowances for each Organizer are determined by a Member Meeting at the suggestion of the Trustee".

The above provisions explain that there is only one type of cooperatives that are applied in Indonesia, namely cooperatives that provide salaries and allowances for Cooperatives Organizers and Trustees. Cooperatives generally consist of two types of cooperatives, the Herman-Schulze cooperatives model in which the organizer gets a salary, while the Friedrich Wilhelm Raiffeisen cooperatives model in which the organizer does not get a salary. When investigated further, the Friedrich Wilhelm Raiffeisen cooperatives model is ideal because the Cooperatives Organizer and Trustees do not spend all day in carrying out administrative affairs of the cooperatives. Administrative activities can be delegated to cooperatives operators. On one occasion to commemorate Cooperatives Day, Hatta made a statement in his remarks that in general, cooperatives Organizer was not given a salary, only operators who worked all day had to receive salaries. The article is against Article 33 section (1) of The 1945 Constitution.

3.2.3 Article 50 section (1) letter a; and Article 50 section (2) letter a and letter e of Law No. 17 of 2012

Based on Article 50 section (1) letter a of Law No. 17 of 2012 regulating that "Trustees are assigned to propose 
prospective organizers".

Based on Article 50 section (2) of Law No. 17 of 2012 regulating the Trustees are authorized:

a. determine the acceptance and rejection of new Members and dismissal of Members in accordance with the provisions in the Articles of Association; and

e. can dismiss Organizer for a temporary by mentioning the reason.

The above provisions explain that the Trustee of cooperatives has a very large authority, even exceeding the authority of meeting members as the highest authority in the Cooperatives. Furthermore, this condition will negate the system of checks and balances which is one of the principles of cooperatives. Organizers nomination, dismissal of members, and dismissal of Organizers are the authority decided at the Members' Meeting. As a result, the relationship between the Organizer and the Trustee of the cooperatives is not at the same level and will cause internal conflict. The article is against Article 33 section (1) of The 1945 Constitution.

3.2.4 Article 55 section (1) of Law No. 17 of 2012

Based on Article 55 section (1) of Law No. 17 of 2012 regulating that "The organizer is chosen from a natural person, both Members as well as non-Members".

The above provisions explain that the existence of Organizers originating from non-members will certainly eliminate the principles of togetherness and familial so that the goal of achieving welfare together will not be realized. The article is against Article 33 section (1) of The 1945 Constitution.

\subsubsection{Article 56 section (1) of Law No. 17 of 2012}

Based on Article 56 section (1) of Law No. 17 of 2012 regulating that "The Organizers are chosen and appointed at the Members' Meeting based on the recommendations of the Trustees".

The above provisions explain that the right of each member to nominate as a candidate for Organizers of cooperatives is reduced or even there is no. Although based on familial principles, the implementation of cooperatives must be done together. By setting limits on the nomination of candidates for Organizers are determined by the trustee, what happens in organizing cooperatives is no longer based on the principle of familial and members of the cooperatives no longer have the same rights and positions. The article is against Article 33 section (1) and Article 28C section (2) of The 1945 Constitution. Adapun based on Article 28C section (2) of The 1945 Constitution regulating that "Each person has the right to self-improvement by way of a collective struggle for his rights with a view to developing society, the nation, and the country".

\subsubsection{Chapter VII of Law No. 17 of 2012 on Capital}

Based on Chapter VII of Law No. 17 of 2012 on Capital regulating that:

Article 66

(1) Cooperatives Capital consists of Principal Deposits and Certificate of Cooperatives Capital as initial capital.

(2) In addition to capital as referred to in section (1) cooperatives capital may originate from:

a. Grant;

b. Capital Participation;

c. loan capital originating from:

1. members;

2. Other cooperatives and/or their members;

3. banks and other financial institutions;

4. issuance of bonds and other IOU; and/or

5. Government and Local Government. and/or

d. another source legitimate that does not conflict with the Articles of Association and/or legislation provisions.

Article 67

(1) The Principal Deposit is paid by the Member when they submit their application as a Member and is non-refundable. 
(2) Principal Deposit as referred to in section (1) must be fully deposited with legitimate proof of deposit.

(3) Provisions regarding the requirements and procedures for determining Principal Deposits in Cooperatives are regulated in the Articles of Association.

Article 68

(1) Each Cooperatives Member must purchase a Cooperatives Capital Certificate with a minimum amount specified in the Articles of Association.

(2) The cooperatives must issue a Cooperatives Capital Certificate with a face value per sheet, the maximum equal to the value of the Principal Deposit.

(3) Purchase a Cooperatives Capital Certificate in a minimum amount as referred to in section (1) is proof of Member Capital Participation in the Cooperatives.

(4) Each Member is given proof of deposit of the Cooperatives Capital Certificate that he has deposited.

Article 69

(1) The Cooperatives Capital Certificate does not have voting rights.

(2) The Cooperatives Capital Certificate as referred to in section (1) is issued in the name.

(3) The face value of the Cooperatives Capital Certificate must be stated in the currency of the Republic of Indonesia.

(4) Deposit of Cooperatives Capital Certificates can be made in the form of money and/or in other forms that can be valued in money.

(5) In the case of depositing Cooperatives Capital Certificates in other forms as referred to in section (4) the appraisal is conducted to obtain fair market value.

(6) The Cooperatives must maintain a list of the certificate of Cooperatives Capital holders and a list of Participation Capital holders that at least contains:

a. the name and address of the Cooperatives Capital Certificate holder and the Participation Capital holder;

b. amount of sheets, number, and date of acquisition of Cooperatives Capital Certificate and Capital Participation;

c. the number and value of the Cooperatives Capital Certificate and the value of Capital Participation; and

d. change of ownership of the Cooperatives Capital Certificate.

Article 70

(1) Transfer of Cooperatives Capital Certificates to other Members may not deviate from the provisions regarding ownership of Cooperatives Capital Certificates in the minimum amount referred to in Article 68 .

(2) Transfer of Cooperatives Capital Certificates by Members is considered legitimate if:

a. The Cooperatives Capital Certificate has been held for at least 1 (one) year;

b. transfers are made to other Members from the same cooperatives;

c. Transfers are reported to the Organizer; and/or

d. no other Members or new Members who are willing to purchase the Cooperatives Capital Certificate for a while the Cooperatives can purchase in advance using Surplus Operating Results for the current year as a bailout with a maximum of $20 \%$ (twenty percent) of Surplus in Operating Results for the financial year.

(3) In the event that membership expires as referred to in Article 28 section (1), the Member concerned must sell the Cooperatives Capital Certificate to other Members from the same cooperatives based on the price of the Cooperatives Capital Certificate determined by the Member Meeting.

Article 71

Changes in the value of Cooperatives Capital Certificates follow the applicable financial accounting standards and are determined in the Member Meeting.

Article 72 
(1) Certificate of Cooperatives Capital from a deceased Member can be transferred to an eligible heir and/or willing to become a Member.

(2) In case the heir does not meet the requirements and/or is not willing to become a Member, the Cooperatives Capital Certificate can be transferred to another Member by the Organizer and the results are submitted to the heirs.

\section{Article 73}

Further provisions regarding the procedures for the sale and transfer of Cooperatives Capital Certificates as referred to in Article 68 to Article 72 are regulated in the Articles of Association.

Article 74

(1) Grants given by third parties originating from foreign capital sources, both directly and indirectly, can be received by the Cooperatives and reported to the Minister.

(2) Grants, as referred to in section (1), cannot be distributed directly or indirectly to Members, Organizers, and Trustees.

(3) Provisions regarding Grants are carried out in accordance with legislation provisions.

Article 75

(1) The cooperatives can receive Capital Participation from:

a. The government is in accordance with legislation provisions; and/or

b. The community based on an agreement on the placement of Capital Participation.

(2) The government and/or community as referred to in section (1) must also bear the risk and be responsible for the loss of business financed with Capital Participation as far as the value of Capital Participation invested in the Cooperatives.

(3) The obligation referred to in section (2) also applies in the event that the Government and/or the community participates in the management of businesses financed by Capital Participation and/or contributes to the occurrence of business losses funded by Capital Participation.

(4) The government and/or community as referred to in section (1) is entitled to get a share of the profits derived from businesses financed by Capital Participation.

Article 76

The placement agreement for capital participation from the community as referred to in Article 75 section (1) letter $b$ shall at least contain:

a. the amount of Capital Participation;

b. risk and responsibility for business losses;

c. business management; and

d. profits derived.

Article 77

Further provisions regarding cooperatives capital as referred to in Article 66 to Article 76 shall be regulated in a Government Regulation.

The provisions above explain that the cooperatives is established based on the principle of basic capital so that the element of brotherhood in the principle of familial will be difficult to realize. This condition will also present an injustice that will bring up members with dominant status as holders of Cooperatives Capital Certificates such as Limited Company capital ownership. Also, foreign parties/governments who are not members can also invest in cooperatives through the capital system. The article is against Article 33 section (1) of The 1945 Constitution.

3.2.7 Article 67 section (1) of Law No. 17 of 2012

Based on Article 67 section (1) of Law No. 17 of 2012 regulating that "The Principal Deposit is paid by the Member when they submit their application as a Member and is non-refundable".

The above provisions explain that Principal Deposits paid when someone wants to apply to a member cannot be returned. Such actions are a form of arbitrary seizure of private property rights. The article is against Article $28 \mathrm{H}$ section (4) of The 1945 Constitution. Based on 28H section (4) of The 1945 Constitution regulating that "Each person has the right to own private property and such ownership shall not be appropriated arbitrarily by 


\section{whomsoever."}

\subsubsection{Article 70 section (2) letter d of Law No. 17 of 2012}

Based on Article 70 section (2) letter d of Law No. 17 of 2012 regulating that the Transfer of Cooperatives Capital Certificates by Members is considered legitimate if:

a. The Cooperatives Capital Certificate has been held for at least 1 (one) year;

b. transfers are made to other Members from the same cooperatives;

c. Transfers are reported to the Organizer; and/or

d. no other Members or new Members who are willing to purchase the Cooperatives Capital Certificate for a while the Cooperatives can purchase in advance using Surplus Operating Results for the current year as a bailout with a maximum of $20 \%$ (twenty percent) of Surplus in Operating Results for the financial year.

The above provisions explain that the Cooperatives can have a Cooperatives Capital Certificate, even though it is known that the cooperatives is established based on the principles of togetherness and familial. In the end, there is a Cooperatives Capital Certificate that is not owned by the members of the Cooperatives. The article is against Article 28H section (4) of The 1945 Constitution

\subsubsection{Article 78 section (2) of Law No. 17 of 2012}

Based on Article 78 section (2) of Law No. 17 of 2012 regulating that "Cooperatives are prohibited from sharing with Members of Surplus Operating Results from transactions with non-Members".

The above provisions explain that cooperatives have led to economic privatization. The economic privatization system is very different from the spirit of cooperatives. Cooperatives are organized to realize the welfare of members and society in general. Then all profits obtained from cooperatives activities also belong to all members. The article is against Article 28D section (2) and 33 section (1) of The 1945 Constitution. Based on Article 28D section (2) of The 1945 Constitution regulating that "Every person is entitled to an occupation as well as to get income and a fair and proper treatment in labor relations".

\subsubsection{Article 80 of Law No. 17 of 2012}

Based on Article 80 of Law No. 17 of 2012 regulating that "In the case of a Business Results Deficit in a Saving and Loan Cooperatives, the Member must add a deposit of the Cooperatives Capital Certificate".

The above provisions explain that cooperatives activities are a form of exploitation to its members. Also, there is no fair and just treatment in working relationships in cooperatives. must be in a cooperatives status as a legal entity (rechtspersoon), member accountability is limited to paid-up "capital". The article is against Article 28D section (2) of The 1945 Constitution.

\subsubsection{Article 82, Article 83, and Article 84 of Law No. 17 of 2012}

Based on Article 82 of Law No. 17 of 2012 regulating that:

(1) Every Cooperatives includes the types of cooperatives in the Articles of Association.

(2) The types of cooperatives referred to in section (1) are based on the similarity in business activities and/or the economic interests of Members.

Based on Article 83 of Law No. 17 of 2012 regulating that the types of cooperatives referred to in Article 82 consist of:
a. Consumer Cooperatives;
b. Producer Cooperatives;
c. Services Cooperatives; and
d. Saving and Loan Cooperatives.

Based on Article 82 of Law No. 17 of 2012 regulating that:

(1) Consumer Cooperatives organizing business activities in the field of providing goods needed by Members and non-Members.

(2) Producer Cooperatives organizing business activities in the field of procurement of production facilities and marketing of production produced by Members for Members and non-Members.

(3) Services Cooperatives organizing business activities services does not-saving and loan needed by Members and non-Members. 
(4) Saving and Loan Cooperatives organizing business saving and loan activities as the only business that serves Members.

The above provisions explain that cooperatives have limits on business activities where each cooperatives has only one type of business. Members will be disadvantaged because the members' needs cannot be met because the cooperatives only operates one type of business. The article is against Article 33 section (1) and section (4) of The 1945 Constitution. based on Article 33 (4) of The 1945 Constitution regulating that:

"The organization of the national economy shall be based on economic democracy that upholds the principles of solidarity, efficiency along with fairness, sustainability, keeping the environment in perspective, self-sufficiency, and that is concerned as well with balanced progress and with the unity of the national economy."

\subsection{Considerations and Decisions of the Constitutional Court against Petitioners' Petition}

After receiving a written conclusion from the Petitioner and before the Constitutional Court considered the constitutional issues as described in the Petitioner, the Constitutional Court first stated several matters relating to the Cooperatives, among others:

1. Indonesia as a citizen who binds itself to become a nation and the country has certain ideas about the economic system that wants to be built in accordance with the values that grow and develop in society.

2. In a constitutional historical perspective, people who then bind themselves into a nation and one of its aims is to improve the welfare of society by realizing social justice for all Indonesian citizens.

3. Social justice for all Indonesian citizens from the aspect of the economic system is the basis of Article 33 section (1) of The 1945 Constitution regulating that "The economy is to be structured as a common endeavor based on familial principles". The provision explains that Indonesia's economic system must be developed by the state. The government should not let the economic system grow and develop naturally according to market mechanisms based on supply and demand.

4. Conceptually, the principles of togetherness and familial forms the economic system of people's sovereignty. This is in line with togetherness in the ties of nationalism and forming their own country freely and independently. This joint effort is the main capital to achieve a common goal, to advance the welfare of society by realizing social justice for all Indonesian citizens. In this joint effort, there are individuals as human resource contributions, including knowledge, expertise, enthusiasm, fighting spirit and so on which are also an important part of the capital, in addition to other capital such as finance, equipment, technology, and others. All individuals struggle together to achieve common goals.

5. Cooperatives are a means of gathering together with the principle of joint efforts in the economic structure as described above on a narrower scale. This principle is a constitutional provision in the 1945 Constitution.

Based on the above considerations, the Constitutional Court will further consider the constitutionality of the articles submitted by the Petitioner. Petitions for constitutionality testing include:

\subsubsection{Definition of Cooperatives}

Considering, the Petitioner postulates that the phrase "natural person" in the cooperatives sense was based on Article 1 point 1 of Law No. 17 of 2012 is against Article 33 section (1) of The 1945 Constitution because that definition leads to individualism.

Observing that understanding is a fundamental problem in law because it contains the philosophy of the entity it regulates, the Constitutional Court will consider not only those related to the phrase "natural person", but also the whole formulation of understanding in the article as follows:

1. Chapter I General provisions of legislation based on Annex II point 107 of Law No. 12 of 2011 is to explain the meaning of words or terms. So, even though it does not contain norms, the definition has an important position in law, especially when the definition is related to other articles. According to the Constitutional Court, cooperatives are part of the Indonesian economic structure mandated by Article 33 section (1) of The 1945 Constitution which is placed in Chapter XIV titled, "National Economy and Social Welfare". On that basis, Article 33 section (1) of The 1945 Constitution can be understood clearly the philosophical meaning. The article was also not changed when the 1945 Constitution was amended. Also, to get an understanding of the formation of the 1945 Constitution, it is important to know the explanation of Article 33 section (1) which states that:

"Article 33 states that there is a basis for economic democracy, production is carried out by all, for all under the leadership or supervision of members of the community. The welfare of community members 
comes first, not individual welfare. Therefore cooperatives are established together based on familial principles. Building a company that is compatible with it is cooperatives".

2. Based on Article 33 section (1) of the 1945 Constitution and its explanation, cooperatives are an important part of the structure of the national economy or the structure of the Indonesian economy. An economic arrangement must be designed following the values which are held in high esteem by the nation that formed this country, the values which then become its character, namely collective values and characters, which are individualistic contradictions. Individualistic values are not adopted by the 1945 Constitution. Therefore, cooperatives as part of the national economic structure must be designed, socialized, championed, and implemented. The structure of the national economy must not be left to the market mechanism, although markets must be an important concern in the international economic arena. Thus, the national economic system is a characterized economic system.

3. To consider whether there is a cooperatives definition in Article 1 point 1 of Law No. 17 of 2012 resembles individualism which was postulated by the Petitioner. Therefore, the Constitutional Court needs to cite the definition of cooperatives in various amended laws for comparison, including:

1) Article 2 section (1) Law No. 79 of 1958 on Cooperatives Association states that:

"Cooperatives are associations of natural person or legal entities that are not a concentration of capital."

2) Article 3 Law No. 14 of 1965 on Cooperatives states that:

"Cooperatives are economic organizations and tools of the Revolution that function as a place for the regeneration of citizens and training towards Indonesian Socialism based on Pancasila."

3) Article 3 Law No. 12 of 1967 on the Essence of the Cooperatives states that:

"Indonesian Cooperatives is a people's economy organization with a social character consisting of natural person or legal entities Cooperatives which is an economic arrangement as a joint effort based on familial principles."

4) Article 1 point 1 Law No. 25 of 1992 on Cooperatives states that:

"Cooperatives is a business entity that is a member of an individual or a legal entity Cooperatives that bases its activities based on the principle of cooperatives as well as the people's economic movement based on familial principles"

By comparing several meanings in various laws, according to the Constitutional Court, it is clear that what is highlighted in the formulation of a cooperatives definition is about who the cooperatives is, or in other words, a formula that prioritizes cooperatives in the perspective of economic agents. This subjective perspective is part of the economic system. For this purpose, it is formulated in words or phrases, associations, economic organizations, or people's economic organizations. Or, at least of Law No. 25 of 1992, the cooperatives was formulated as a "business entity". This formula is very different from Article 1 point 1 of Law no. 17 of 2012 which states that cooperatives are legal entities. The formula that a cooperatives is a legal entity does not contain a substantive understanding of cooperatives as referred to in Article 33 section (1) of the 1945 Constitution and explanations that refer to the understanding as a definition as building a typical company. Therefore, the Petitioner's argument is grounded according to law.

\subsubsection{Salary Organizer and Trustee Allowance}

Considering, The Petitioners postulates Article 37 section (1) letter $\mathrm{f}$ and Article 57 section (2) of Law No. 17 of 2012 is against Article 33 section (1) of The 1945 Constitution. Regarding this issue, the Constitutional Court considered the following matters:

1. Principal case Article 37 section (1) of Law No. 17 of 2012 contains the norm as based on Article 1 point 5 of Law No. 17 of 2012 states that "Members Meeting is a tool of the Cooperatives organization which holds the highest authority in the Cooperatives" jo. Article 32 of Law No. 17 of 2012 regulating that "Members Meeting is a tool of the Cooperatives organization which holds the highest authority in the Cooperatives". Then based on Article 33 letter f of Law No. 17 of 2012 regulating that "Members Meeting have the authority to request and ratify accountability report of Trustees and Organizers in carrying out their respective duties". Therefore, based on Article 50 letter d of Law No. 17 of 2012 regulating that "The Trustee is responsible for reporting the results of supervision to the Member Meeting". Furthermore, based on Article 58 letter d of Law No. 17 of 2012 regulating that "The Organizer has the duty to prepare financial reports and responsibilities for reporting the results of task implementation to the Member Meeting". Specifically for financial reports consists of the number 
of allowances for trustees as well as salaries and other allowances for organizers. According to the Constitutional Court, the material on the contents of financial statements as part of the accountability report is a natural thing when the trustee and organizer do get it. Therefore, the Petitioner's argument is not grounded according to law.

2. Principal case Article 57 section (2) of Law No. 17 of 2012 contains the norm as based on Article 49 section (3) of Law No. 17 of 2012 regulating that "The amount of allowance for Trustees is determined in the Member Meeting". then the Constitutional Court considered the following matters:

1) Based on Article 1 point 6 of Law No. 17 of 2012 states that "a trustee is a tool of the Cooperatives organization that is responsible for overseeing and advising the Organizer" jo. Article 50 section (1) of Law No. 17 of 2012 regulating that Trustee on duty:

a. propose an organizer candidate;

b. overseeing and advising the Organizer;

c. supervise the implementation of Cooperatives of the policies and management carried out by the Organizer; and

d. reporting the results of supervision to the Member Meeting.

2) Based on Article 1 point 7 of Law No. 17 of 2012 states that:

"An organizer is a tool of the Cooperatives organization that is fully responsible for the management of cooperatives for the interests and needs of cooperatives and represents cooperatives both inside and outside the court in accordance with the provisions of the Articles of Association."

jo. Article 58 of Law No. 17 of 2012 regulating that Organizer on duty:

a. managing cooperatives based on Articles of Association;

b. encourage and advance the business of Members;

c. draw up a draft work plan and Cooperatives income and expenditure budget plan to be submitted to the Member Meeting;

d. make a plan for financial statements and responsibilities for task implementation to be submitted to the Member Meeting;

e. make a plan for education, training, and communication of cooperatives to be submitted to the Member Meeting;

f. conducting financial accounting and inventory in an orderly manner;

g. manage employee coaching effectively and efficiently;

h. maintain a Member List Book, Trustee List Book, Organizer List Book, certificate of Cooperatives Capital holders List Book, and Minutes of Member Meetings; and

i. make other efforts for the interests, benefits, and progress of the Cooperatives in accordance with their responsibilities and the decisions of the Member Meeting.

3) Ideally, the cooperatives organizer does not get a salary. Cooperatives organizers only get transportation money each time they attend a hearing. In a cooperatives that gets a salary are those who continue to work as directors and workers of a cooperatives company whose salary should not be lower than ordinary private companies.

When the conditions of the cooperatives were still very simple, Organizers and trustee activities were relatively small so that they could work elsewhere to meet the economic needs of their families. But if the cooperatives has succeeded in certain parts, it will affect the busyness of the Organizer and Trustee. Whether it is fair if in such circumstances the Organizers and the trustees are not given salary and allowances? Therefore, the Petitioner's argument is not grounded according to law.

\subsubsection{Duties and Authorities of the Trustee}

Considering, The Petitioners postulates Article 50 section (1) letter a; and Article 50 section (2) letter a and letter e; and Article 56 section (1) of Law No. 17 of 2012 is against Article 28C section (2) and Article 33 section (1) of The 1945 Constitution. The specific problem of this article regulating that:

1. The task of the trustee proposes the organizer; 
2. The trustee authority accepts and rejects new members and terminates members; and

3. The trustee authority temporarily suspends the organizer.

From the conclusion of the above provisions, the Constitutional Court considers that the duties and authority of the trustee must be related to the nature of cooperatives, namely democratic. Based on Article 5 section (1) letter d and letter e of Law No. 17 of 2012 regulating that the values that underlie Cooperatives activities, namely:

d. democracy;

e. equation.

In accordance with this character, cooperatives members are the highest sovereign holders so they are based on Article 29 section (2) letter $\mathrm{c}$ of Law No. 17 of 2012 regulating that "The member ... has the right to choose and/or be chosen as Trustee or Organizer". So concerning cooperatives organizers, members have the right to choose members who will be organizers and at the same time members also have the right to be chosen as organizers. Based on Article 33 letter c of Law No. 17 of 2012 regulating that "Members of the Meeting have the authority to elect, appoint and dismiss Trustees and Organizers".

Based on the above considerations, the Constitutional Court considers that there is a conflict between Article 50 section (1) letter a; section (2) letter a and letter e; and Article 56 section (1) of Law No. 17 of 2012, where each article gives supervisors the task of proposing the organizer, accepting and rejecting new members, terminates members, and temporarily suspending the organizer, is against Article 5 section (1) letter d and letter e; and Article 29 section (2) letter c of Law No. 17 of 2012, where democracy and equality are the basic values of cooperatives activities and the right for members to vote and be elected. So that also means contrary to the principles of economic democracy as referred to in Article 33 section (1) of The 1945 Constitution. That with the authority of the Trustees, will reduce and even eliminate the sovereignty of members and the existence of a Member Meeting. Therefore, the Petitioner's argument is grounded according to law.

\subsubsection{Appointment of Organizers from Non-Members}

Considering, The Petitioners postulates Article 55 section (1) of Law No. 17 of 2012 is against Article 33 section (1) of The 1945 Constitution. Regarding this issue, the Constitutional Court considers specifically that this provision impedes or is against Article 29 section (2) letter a and letter c of Law No. 17 of 2012 regulating that Members ... have the right:

a. to attend, express opinions and vote in a Member Meeting; and

c. to choose and/or be chosen as a Trustee or Organizer.

Based on Article 5 section (1) letter a, letter c, letter d, and letter e of Law No. 17 of 2012 regulating that the values that underlie Cooperatives activities, namely:
a. familial;
c. to be responsible;
d. democracy; and
e. equation.

Furthermore, based on Article 5 section (2) letter b and letter $\mathrm{c}$ of Law No. 17 of 2012 regulating that the values believed by the Cooperatives Members, namely:

b. openness; dan

c. to be responsible.

From the above provisions, everything is a derivation of the economic democratic system based on Article 33 section (1) of The 1945 Constitution. If the reason is to build a more professional cooperatives, cooperatives members must be given training so that they have high professionalism. Therefore there is no need to recruit non-members to become organizers, even members can be recruited as cooperatives operators. Therefore, the Petitioner's argument is grounded according to law.

\subsubsection{Cooperatives Capital}

Considering, The Petitioners postulates Chapter VII of Law No. 17 of 2012 on Cooperatives Capital consists of Article 66 through Article 77 is against Article 28H section (4) and Article 33 section (1) of The 1945 Constitution. Regarding this issue, the Constitutional Court considered the following matters:

1. Principal case Article 66 of Law No. 17 of 2012 contains the norm as based on Article 1 point 8 through 
point 11 of Law No. 17 of 2012 states that:

8. Principal Deposit is a sum of money, which must be paid by a natural person or a Cooperatives legal entity when the person concerned wants to be a member of the cooperatives.

9. Certificate of Cooperatives Capital is proof of inclusion of Cooperatives Members in Cooperatives capital.

10. Grant is a gift in the form of money and/or goods to the Cooperatives voluntarily without compensation, as business capital.

11. Capital Participation is a capital deposit in a cooperatives in the form of money and/or goods that can be valued with money deposited by a natural person and/or legal entities to increase and strengthen cooperatives capital to increase their business activities.

2. Principal case Article 67 of Law No. 17 of 2012 contains the norm as based on Article 1 point 8 of Law No. 17 of 2012. According to the Constitutional Court, the term Principal Deposit emphasizes more on its understanding as to the surrender of some money as capital, so that the consequences cannot be withdrawn if the person concerned leaves or is no longer a member of the cooperatives. This differs from the use of the term Principal Deposit, which means that cooperatives members save a certain amount of money as capital. Cooperatives are a safe place for members because the management is a fellow member and can be trusted. Thus, every member who pays Primary Deposit as Cooperatives Capital, if he wants to leave or stop for some reason, his Primary Deposit can be taken back. If Article 67 section (1) remains a provision, the meaning of permanent membership in a cooperatives is coercion. The article is against Article 6 section (1) letter a of Law No. 17 of 2012 regulating that "Cooperatives implement the Cooperatives Principles which include cooperatives membership that is voluntary and open" which is a derivative of Article 33 section (1) of The 1945 Constitution.

3. Principal case Article 68 and Article 69 of Law No. 17 of 2012 contains the norm as based on Article 1 point 9 of Law No. 17 of 2012. According to the Constitutional Court, requiring cooperatives members to purchase a Cooperatives Capital Certificate is a norm that is not following the voluntary and open principles of cooperatives. Material and financial capital are important, but the concept of cooperatives capital must mean "structured economics as a joint venture based on familial principles". The article is against Article 6 section (1) letter a of Law No. 17 of 2012 which is a derivative of Article 33 section (1) of The 1945 Constitution.

4. Principal case Article 70 section (2) letter d of Law No. 17 of 2012 contains the norm as based on Article 67 and Article 68 of Law No. 17 of 2012. According to the Constitutional Court, the member will lose ownership of the Cooperatives Capital Certificate when no other member purchase or the bailout fund is insufficient. Although the intention is the existence of Cooperatives Capital Certificates and Principal Deposits which cannot be withdrawn as part of efforts to strengthen cooperatives capital. However, this method is not appropriate because it contradicts familial principles as explained above. The article is against Article $28 \mathrm{H}$ section (4) and Article 33 section (1) of The 1945 Constitution.

5. Principal case Article 70 section (2) letter d of Law No. 17 of 2012 contains the norm as based on Article 67 and Article 68 of Law No. 17 of 2012. According to the Constitutional Court, the cooperatives as a pool of natural person capital are no different from companies with limited liabilities that open up broad investment opportunities and interventions from non-members.

Although not all articles in Chapter VII of Law No. 17 of 2012, based on the above considerations, the Petitioners' argument is grounded according to law.

\subsubsection{Prohibition of Distribution of Surplus Operating Results from Transactions with non-Members}

Considering, The Petitioners postulates Article 78 section (2) and Article 80 of Law No. 17 of 2012 is against Article 28D section (2) and Article 33 section (1) of The 1945 Constitution. Regarding this issue, the Constitutional Court considered the following matters:

1. Principal case Article 78 section (2) and Article 80 of Law No. 17 of 2012 contains the norm as based on Article 1 point 12 of Law No. 17 of 2012 states that "Difference in Operating Results is a Surplus Operating Results or deficit Operating Results obtained from operating results or Surplus Results of Cooperatives Operations for the current year after deducting costs for various operational costs". Based on these provisions, members are not entitled to surpluses -even if they come from transactions with non-members- but when a cooperatives experiences a deficit in operating results, whether caused by a transaction with a member or not a member, the member must deposit the Cooperatives Capital Certificate as additional capital.

2. Members of the cooperatives as the essence of the formation of cooperatives, then entitled to get the 
Overall Surplus Results of Cooperatives Operations. Members of the cooperatives as the essence of the formation of cooperatives, then entitled to get the Overall Surplus Results of Cooperatives Operations. Therefore this provision is very distorted because it ignores members as cooperatives owners.

Based on the explanation above, the article is against Article 28D section (2) and Article 33 section (1) of the 1945 Constitution. Therefore, the Petitioner's argument is grounded according to law.

\subsubsection{Type of Cooperatives}

Considering, The Petitioners postulates Article 82, Article 83, and Article 84 of Law No. 17 of 2012 is against Article 33 section (1) and section (4) of The 1945 Constitution. Regarding this issue, the Constitutional Court considered the provisions in the article contain definitions of restrictions on the types of business activities that can be carried out by cooperatives.

According to the Constitutional Court, restrictions on the types of cooperatives business activities to only four types has inhibits the creativity of cooperatives to determine their types of business activities. Therefore, restrictions on the type of cooperatives threaten the flexibility of cooperatives development. Furthermore, cooperatives as a joint effort must be supported to present various types of businesses, because each member has different needs from one another. Therefore, the Petitioner's argument is grounded according to law.

\subsubsection{Decision}

1. To grant the petition of the Petitioners entirely.

2. Law No. 17 of 2012 against The 1945 Constitution;

3. Law No. 17 of 2012 has no binding legal force;

4. Law No. 25 of 1992 valid for a while awaiting the establishment of a new Law;

5. To order the placing of this ruling in the Gazette of the state of the Republic of Indonesia as it should be.

\section{Conclusion}

Based on the legal review on Decision of the Constitutional Court No. 28/PUU-XI/2013, Phrase "natural person" in the cooperatives sense was based on Article 1 point 1 of Law No. 17 of 2012 is against Article 33 section (1) of The 1945 Constitution because that definition leads to individualism. The Petitioners postulates concerning Duties and Authorities of the Trustee where the Constitutional Court considers that there is a conflict between Article 50 section (1) letter a; section (2) letter a and letter e; and Article 56 section (1) of Law No. 17 of 2012 is against Article 5 section (1) letter d and letter e; and Article 29 section (2) letter c of Law No. 17 of 2012. Furthermore, although the Petitioner's petition is only regarding certain articles it contains substantial norm content, it will cause other articles in Law No. 17 of 2012 has no binding legal force. Therefore the Petitioner's petition must be declared in accordance with the law for all contents of Law No. 17 of 2012. As for the sake of legal certainty, Law No. 25 of 1992 valid for a while awaiting the establishment of a new Law.

\section{References}

Asshiddiqie, J. (2006). Hukum Acara Pengujian Undang-Undang. Jakarta: Konstitusi Press.

Begem, S. S., Qamar, N., \& Baharuddin, H. (2019). Sistem Hukum Penyelesaian Pelanggaran Hak Asasi Manusia (HAM) Berat Melalui Mahkamah Pidana Internasional. SIGn Jurnal Hukum, CV. Social Politic Genius (SIGn), 1(1), 1-17. https://doi.org/10.37276/sjh.v1i1.28

Decision of the Constitutional Court of the Republic of Indonesia Number 28/PUU-XI/2013 on the Review of Law Number 17 of 2012 on Cooperatives against the 1945 Constitution of the Republic of Indonesia.

Government Regulation in Lieu of Law of the Republic of Indonesia Number 1 of 2013 on the Second Amendment to Law Number 24 of 2003 on The Constitutional Court. State Gazette of the Republic of Indonesia of 2013 Number 167. Supplement to the State Gazette of the Republic of Indonesia Number 5456.

Gracia, J. J. E. (1990). Texts and Their Interpretation. The Review of Metaphysics, Philosophy of Education Society, Inc., 43(3), 495-542.

Hastangka, H., Armawi, A., \& Kaelan, K. (2018). Analisis Putusan Mahkamah Konstitusi Nomor 100/PUU-XI/2013 tentang Pembatalan Frasa 4 Pilar Kehidupan Berbangsa dan Bernegara. Mimbar Hukum, Universitas Gadjah Mada, 30(2), 230-245. https://doi.org/10.22146/jmh.32660

Hatta, M. (2002). Kumpulan Pidato (Vol. 2). Jakarta: Gunung Agung. 
Hendrojogi. (2007). Koperasi Asas-Asas, Teori, dan Praktik. Jakarta: PT. Raja Grafindo Persada.

Law of the Republic of Indonesia Number 79 of 1958 on Cooperatives Association. State Gazette of the Republic of Indonesia of 1958 Number 139. Supplement to the State Gazette of the Republic of Indonesia Number 1669.

Law of the Republic of Indonesia Number 14 of 1965 on Cooperatives. State Gazette of the Republic of Indonesia of 1965 Number 75. Supplement to the State Gazette of the Republic of Indonesia Number 2769.

Law of the Republic of Indonesia Number 12 of 1967 on the Essence of the Cooperatives. State Gazette of the Republic of Indonesia of 1967 Number 23. Supplement to the State Gazette of the Republic of Indonesia Number 2832.

Law of the Republic of Indonesia Number 25 of 1992 on Cooperatives. State Gazette of the Republic of Indonesia of 1992 Number 116. Supplement to the State Gazette of the Republic of Indonesia Number 3502.

Law of the Republic of Indonesia Number 24 of 2003 on The Constitutional Court. State Gazette of the Republic of Indonesia of 2003 Number 98. Supplement to the State Gazette of the Republic of Indonesia Number 4316.

Law of the Republic of Indonesia Number 48 of 2009 on The Judicial Powers. State Gazette of the Republic of Indonesia of 2009 Number 157. Supplement to the State Gazette of the Republic of Indonesia Number 5076.

Law of the Republic of Indonesia Number 8 of 2011 on Amendment to Law Number 24 of 2003 on The Constitutional Court State Gazette of the Republic of Indonesia of 2011 Number 70. Supplement to the State Gazette of the Republic of Indonesia Number 5226.

Law of the Republic of Indonesia Number 12 of 2011 on Legislation Making. State Gazette of the Republic of Indonesia of 2011 Number 82. Supplement to the State Gazette of the Republic of Indonesia Number 5234.

Law of the Republic of Indonesia Number 17 of 2012 on Cooperatives. State Gazette of the Republic of Indonesia of 2012 Number 212. Supplement to the State Gazette of the Republic of Indonesia Number 5355 .

Law of the Republic of Indonesia Number 4 of 2014 on Enactment of Government Regulation in Lieu of Law Number 1 of 2013 on the Second Amendment to Law Number 24 of 2003 on The Constitutional Court Into Law. State Gazette of the Republic of Indonesia of 2014 Number 5. Supplement to the State Gazette of the Republic of Indonesia Number 5493.

Marsuni, L. (2017). Hukum Kelembagaan Negara di Indonesia. Makassar: Liblitera Institute.

The 1945 Constitution of the Republic of Indonesia.

Yuwana, N., Nugroho, H., \& Abdullah, I. (2012). Kontestasi Elit dan Marginalisasi Penduduk Lokal di Lokasi Pertambangan Batubara Kutai Kartanegara. Jurnal Pemikiran Sosiologi, Universitas Gadjah Mada, 1(2), $1-20$.

\section{Copyrights}

Copyright for this article is retained by the author(s), with first publication rights granted to the journal.

This is an open-access article distributed under the terms and conditions of the Creative Commons Attribution license (http://creativecommons.org/licenses/by/4.0/). 